Dušan Stanojević ${ }^{1 *}$, Mirjana Antonijević-Nikolić ${ }^{2}$, Ljubica Mijić ${ }^{2}$, Leposava Filipović-Petrović ${ }^{2}$, Ana Matić ${ }^{2}$

${ }^{1}$ Faculty of Technology, Zvornik, The Republic of Srpska, BiH

${ }^{2}$ Higher Medical and Business-Technological School of Applied Studies, Šabac, Serbia
Scintific paper

ISSN 0351-9465, E-ISSN 2466-2585

UDC:661.183.81.021.4-168

doi:10.5937/ZasMat1803338S

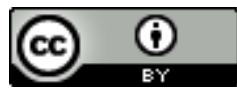

Zastita Materijala 59 (3)

$338-346(2018)$

\title{
Electrochemical method of obtaining calcium-gluconate
}

\begin{abstract}
Gluconic acid and its salts have a wide application in many branches of industry, medicine and pharmacy. Calcium-gluconate can be obtained by gluconic acid reaction with suitable calcium compounds. The applied method was of obtaining calcium-gluconate by electrolysis aqueous glucose solution in the presence of $\mathrm{KBr}$ and $\mathrm{CaCO}_{3}$., while obtained gluconic acid in the reaction with calcium-carbonate gives calcium-gluconate. It is proven that by applying an electrochemical process and subsequent procedure of purification, calcium-carbonate monohydrate can be obtained, without bromides additives. It is also proven that ethanol, being used in the process, can be recycled and used again, making the process more economical and ecologically advanced. Based on research results, block diagram of pilot-plant process of obtaining calcium-gluconate monohydrate was suggested.
\end{abstract}

Keywords: calcium-gluconate, electrochemical procedure, removal of bromides.

\section{INTRODUCTION}

Gluconic acid is non-corrosive, poorly vaporable and non-toxic monoprotic organic acid. It is a natural ingredient of some drinks and food (in wine it is presented up to $1 \%$, and in honey up to $0,5 \%)$. Gluconic acid salts as well as the acid itself are applied in many areas of industry and medicine. If D-glucose (a dominant form of glucose found in nature) was used for obtaining gluconic acid, and later the gluconate, then other products consequently have this mark (D-gluconic acid, etc.). The most important application out of gluconic acid salts have sodium, calcium, potassium, zinc and iron-gluconate.

Gluconates are obtained by the reaction of gluconic acid on hydroxides or carbonates of the adequate metals. Depending on the application, quality, purity and characteristics of gluconic acid and gluconates are determined by appropriate regulations (Codex Alimentarius, Pharmacopoeia, chemical standards, etc.). Yearly production of gluconic acid in the world is around $60.000 \mathrm{t}$. Having in mind that gluconic acid and gluconates are applied in industry branches that constantly expand, their production and consumption increase year after year [1].

\footnotetext{
${ }^{*}$ Corresponding author: Dušan Stanojević

E-mail: dusanstanojevic342@gmail.com

Paper received: 23. 11. 2017.

Paper accepted: 15. 02. 2018.

Paper is available on the website:

www.idk.org.rs/journal
}

Gluconic acid is formed by glucose oxidation in a base environment. For the first time gluconic acid was synthetically obtained almost one hundred and fifty years ago by chemical glucose oxidation, while numerous procedures that were based upon electrochemical, biochemical and bio electronical reactions were developed later. In these processes glucose oxidation was carried out under the influence of electrochemically generated oxidizing agents, i.e. different bacteria and fungi reaction [24].

Apart from transferring glucose into gluconic acid, which occurs by aldehyde group oxidation on glucose molecule, other products are possible depending on the reaction conditions. Oxidation can be performed on the primary alcohol group applying suitable reaction conditions, while the aldehyde group is preserved, when glucuronic acid is obtained. If the oxidation is performed both on aldehyde and alcohol group, diprotic-glucaric acid (gluco-saccharic acid) is formed [1]. Figure 1 shows the D-glucose formula and the possible products of its oxidation.

Today gluconic acid is mostly produced by biochemical methods whereby glucose conversion into gluconic acid is almost hundred percent, but the process is relatively slow. New, highly efficient procedures based on catalytical oxidation of glucose with oxygen on a carbon surface modified with gold, palladium or platinum nanoparticles are intensively explored [1,5-9]. 


$$
\begin{gathered}
\mathrm{H} \\
\mathrm{I}=\mathrm{C} \\
\mathrm{I}=\mathrm{O} \\
\mathrm{H}-\mathrm{C}-\mathrm{OH} \\
\mathrm{I} \\
\mathrm{OH}-\mathrm{C}-\mathrm{H} \\
\mathrm{I} \\
\mathrm{H}-\mathrm{C}-\mathrm{OH} \\
\mathrm{I}-\mathrm{C}-\mathrm{OH} \\
\mathrm{I} \\
\mathrm{CH}_{2} \mathrm{OH}
\end{gathered}
$$

Glucose

$$
\begin{gathered}
\mathrm{COOH} \\
\text { I } \\
\mathrm{H}-\mathrm{C}-\mathrm{OH} \\
\mathrm{I}-\mathrm{C}-\mathrm{H} \\
\mathrm{I}-\mathrm{I}-\mathrm{OH} \\
\mathrm{H}-\mathrm{I} \\
\mathrm{H}-\mathrm{C}-\mathrm{OH} \\
\text { I } \\
\mathrm{C} \mathrm{H}_{2} \mathrm{OH}
\end{gathered}
$$

Gluconic acid

$$
\begin{gathered}
\mathrm{H} \\
\mathrm{C}=\mathrm{O} \\
\mathrm{I}=\mathrm{O} \\
\mathrm{H}-\mathrm{C}-\mathrm{OH} \\
\mathrm{IO}-\mathrm{C}-\mathrm{H} \\
\mathrm{I}-\mathrm{C}-\mathrm{OH} \\
\mathrm{H}-\mathrm{l} \\
\mathrm{H}-\mathrm{C}-\mathrm{OH} \\
\mathrm{I} \\
\mathrm{COOH}
\end{gathered}
$$

Glucuronic acid<smiles>O=C(O)C(O)C(O)C(O)C(=O)O</smiles>

Gluco-saccharic acid

Figure1. D-glucose and possible products of its oxidation

Slika1. D-glukoza i mogući proizvodi njene oksidacije

The biggest consumption of gluconic acid salts has sodium-gluconate that is used in the building industry as cement additive, in the leather processed industry, especially in tanned skin and fur processing, in the food industry: meat, milk and dairy products processing, in maintaining hygiene in production plants. Calcium gluconate has the application in medicine - in calcium therapy (a deficit of calcium in the human and animal organisms), as well as antidote with oxalic acid and fluor poisoning in the fruit juice production, as an additive in cattle food, in the diet and prevention of dairy cattle lactation disorder, etc. [10,11].

During the 20th century gluconic acid, being a base raw material for obtaining calcium-gluconate, was industrially produced by electrochemical oxidation of glucose in the presence of bromide ions. This method was replaced by different microbiological procedures in which the biochemical oxidation of glucose to gluconic acid was performed by different microorganisms, such as: $A$. fumaricus, $P$. leuteum, $P$. purpurogenum, Gluconobacter oxydans, Gluconobacter suboxydans and Pseudomonas fluorescens, Aspergillus Niger, etc. [11]. The reasons for abandoning the electrochemical procedure, at the time, were based on the high price of electrical energy, and especially on the inevitable presence of bromide in the product. However, as a rule, biochemical procedures are very slow and demand significant plant capacities in which the process is carried out, and the product does not often have a high purity, so, especially for medical and pharmacological application additional refinement with complex procedures must be applied. For these reasons in the previous years, a whole set of new procedures is present for obtaining gluconic acid, above all, catalytic, but also electrochemical glucose treatments are coming back to the domain of researchers' interests [12]. Electrochemical processes of obtaining gluconic acid and gluconates through bromides are improved by applying different electrode materials, types of electrolytic cells and process performing conditions [13].

This paper considers the electrochemical process of obtaining calcium-gluconate through bromide with using cheap electrode materials on enlarged laboratory apparatus. In relation to numerous electrochemical processes of this type, defined during the 20th century, special attention was given to the efficiency increase of refining bromide, as well as the possibility to make the technological process of obtaining calciumgluconate more economical with a higher degree of closing (finishing) the recycle process of some phase products.

\section{ELECTROCHEMICAL PROCEDURE OF OBTAINING CALCIUM-GLUCONATE}

The essence of an electrochemical method of obtaining calcium-gluconate is in the electrochemical glucose oxidation in gluconic acid which having been obtained in the same solution, reacts with some of the present calcium compounds (carbonate, hydroxide). Glucose oxidation occurs indirectly, through the elementary brome that is electrochemically generated on the anode. The glucose oxidation process itself to gluconic acid is studied into details $[1,12,14]$, so it will not be the topic of this paper, but some related, basic facts will be stated.

Aqueous glucose solution, to which bromides are added (most often $\mathrm{KBr}$, but also $\mathrm{CaBr}_{2}$ or $\mathrm{NaBr}$ ), is submitted to electrolysis by using a nondiluted anode, while the cathode material, on which the hydrogen-ion reduction flows (hydrogen evolution) can be of different materials, and most often copper. Non-diluted anodes can be of different materials: from cheap and less durable, such as graphite, to more durable and expensive noble metals, or more available - dimensional stable titanium anodes protected with thin noble metal oxide layers [15]. 
Bromide oxidation on the anode makes elementary brome (equation 1). The formed brome with water, in the ratio in which it is dissolved (it is poorly dissolved in water), gives hydrobromic acid and hypobromite acid (reaction 2):

$$
\begin{aligned}
& 2 \mathrm{Br}^{-}-2 \mathrm{e} \rightarrow \mathrm{Br}_{2} \\
& \mathrm{Br}_{2}+\mathrm{H}_{2} \mathrm{O} \rightleftarrows \mathrm{HBr}+\mathrm{HBrO}
\end{aligned}
$$

New researches of glucose oxidation mechanism include tribromide-ion $\left(\mathrm{Br}_{3}{ }^{-}\right)$, which is undoubtedly more correct [14], but it is of no significance for a simple process demonstration on the anode given here.

Brome and hypobromite-ion (is obtained by hypobromite acid dissociation), represent mild oxidants that oxidize the aldehyde group on glucose with obtaining gluconic acid, whereby they reduce themselves to bromide-ion (reactions 3 and 4):<smiles>O=CC(O)C(O)C(O)C(O)CO</smiles>

Glucose<smiles>O=C(O)C(O)C(O)C(O)C(O)CO</smiles>

Gluconic acid

$$
\begin{aligned}
& \mathrm{Br}_{2}+2 e \rightarrow 2 \mathrm{Br}^{-} \\
& \mathrm{BrO}^{-}+2 e \rightarrow \mathrm{Br}^{-}+\mathrm{O}^{2-}
\end{aligned}
$$

Bromide-ions obtained during glucose oxidation reach the anode, oxidize to brome again (reaction 1). The obtained brome, according to reaction 2 , makes further glucose oxidation possible (reactions 3 and 4), and that is why the process flows in continuity. On the electrical cell cathode hydrogen is evolved. In the electrolyte, the obtained gluconic acid, as it is shown in reaction scheme, picture 2., chemically reacts with the present calcium compound (e.g. Calcium carbonate), forming calcium gluconate while carbon dioxide and water are separated (carbonic acid). The efficiency of obtaining calcium gluconate is caused by favourable conditions for electrochemical and chemical reaction degree.

Figure 2. Reaction scheme of forming calcium-gluconate

Slika 2. Reakciona shema nastanja kalcijum-glukonata

As a rule, pure calcium gluconate can be electrochemically obtained regarding the content of other glucose oxidation products, although it contains less or larger bromide quantities and nonreacted glucose. For that reason, it is of great interest that the bromide content in calciumgluconate is decreased to an allowed level by additional purification for the projected product use. Bromide elimination from calcium-gluconate has been the subject of wide researches by various authors $[16,17]$.

Calcium gluconate is produced in different qualities, depending on the application field. For the use in pharmacy and medicine, it must completely meet the pharmacopoeias of every State (for example, today the EU implements the 9th edition that is edited every three years, [18]), and one of the commercial qualities of calcium gluconate intended for other purposes, meets the following demands [19]:

- Purity, not less than $99 \%$ calcium gluconate
- Aqueous solution of calcium-gluconate $10 \%$ at temperature of $60^{\circ} \mathrm{C}$ - colourless

- As, less than 2 ppm

- Heavy metals, less than 20 ppm

- Reducing sugars - none

- Sulfates, less than 500 ppm

- Chlorides, less than 900 ppm

\section{EXPERIMENTAL PART}

Experiments for obtaining calcium-gluconate are conducted in enlarged laboratory apparatus with the aim of developing and improving preliminary results obtained in the previous phase of laboratory researches. Preliminary research results show that the efficiency of the electrochemical process of obtaining calcium gluconate depends on numerous parameters, such as: the electrolyte content, anode current density, temperature, method of adding calcium-carbonate, intensity of mixing the reaction solution. An electolite cell in a glass shape (volume 2l) in which (in a bag of filter- 
fiber) an electrographite anode $\left(\rho=1,83 \mathrm{~kg} / \mathrm{dm}^{3}\right)$ was placed in centre, dimensions $1,2 \mathrm{dm} \times 1,0 \mathrm{dm} \times$ $0,1 \mathrm{dm}$, between two cathodes of copper sheets dimensions $1,2 \mathrm{dm} \times 1,0 \mathrm{dm} \times 0,03 \mathrm{dm}$ were used in the experiments. The space between different electrodes was $0,1 \mathrm{dm}$. The electrolytic cell is placed in a larger glass bowl through which, when necessary, water circulation for cooling is possible. The entire equipment is placed, on a plate of magnetic stirrer with a heating option. The electrolyte is constantly mixed during the process. Before beginning the experiments, the solution is heated to the desired temperature, in order to, if necessary, sustain the desired temperature in the determined range by warming the magnetic stirrer heating plate. Due to water evaporation, in order to prevent uncontrolled electrolyte composition change, distilled water is regularly added to the reaction solution during longer experiments to the started volume. Bag of filter-fiber in which the anode was placed protected the electrolyte from getting dirty because of graphite particles that were generated during the anodes' work. The layer of the formed powder graphite before the new experiment was removed with sandpaper from the surface of the anode, after which the anode was rinsed under a jet of distilled water, while the cathodes were rinsed first in a solution of sulfuric acid 1:1 with the duration of 2-3 minutes, and afterwards with distilled water. As a current source a stabilized adapter of $50 \mathrm{~A}$ - 40V capacity was used, with the possibility of current regulation.

The content of D-glucose in electrolyte and the amount of added calcium carbonate were determined in previous laboratory researches, and for both components the amount is $0,5 \mathrm{~mol} / \mathrm{dm}^{3}$ each. The bromide content in preliminary researches was not definitely determined, because a larger content of bromide increases the electrochemical degree, decreasing the duration of the process, but at the same time, it increases the bromide content in crystal calcium gluconate, so additional optimization of this parameter was needed. All used chemicals were by Fluka company, pro analysis purity.

The recommended temperature for the process, according to used literature sources, was between $40^{\circ}$ and $50^{\circ} \mathrm{C}[1,10]$. Performed experiments in this paper, for the purpose of analysis, gave unfavourable results at the temperatures of $30^{\circ}$ and $60^{\circ} \mathrm{C}$, so the adopted temperature was $45^{\circ}$ with an allowed tolerance of $\pm 3^{\circ} \mathrm{C}$.

$\mathrm{pH}$-value of a working electrolyte was not specially adjusted (it was from 6,5 to 7,5 ) although there are data that the glucose oxidation reaction can be accelerated by applying higher $\mathrm{pH}$-values [14].
Hydrodynamic conditions in the cell are of importance for the process efficiency because the reaction between electrochemically generated oxidants and glucose considerably depends on the intensity of stirring the reaction solution $[13,14]$. Magnetic stirrer, however, does not enable the best possible stirring because at higher speeds the propeller is disattached from the bottom, making stirring uncontrolled, or completely finished. Our previous laboratory experiences showed that for more efficient reactions in cell, it would be the best if the cell was of flow type. However, this demand at the level of increased laboratory experiment (bench scale) could not be realized, so at this level of research a magnetic stirrer was used (diameter $8 \mathrm{~mm}$, length $50 \mathrm{~mm}, \mathrm{n}=300 \mathrm{~min}^{-1}$ ).

After finishing each experiment, the reaction solution was cooled down at room temperature, and afterwards filtrated through the finest analytical filter-paper obtaining calcium-gluconate, nonreacted glucose and $\mathrm{KBr}$ in liquid form, while solid phase - sediment, contains nonreacted $\mathrm{CaCO}_{3}$ with admixture of glucose, $\mathrm{KBr}$ and calcium-gluconate (in the remaining humidity) and the finest graphite particles. The same ethanol volume was added to the measured filtrate volume. After leaving the filtrated solution for 48 hours for crystallization purpose, calcium-gluconate was separated by filtration with the finest filter paper.

In order to examine the possibility of removing bromide from the crystal calcium-gluconate, numerous recommended methods were considered in detail [20]. These methods include bromide precipitation in the filtrate after finishing glucose oxidation phase with different precipitation reagents, such as: base lead-carbonate $\left(\mathrm{PbCO}_{3}\right)_{2} \mathrm{~Pb}(\mathrm{OH})_{2}$, silver-nitrate and silver-oxide, i.e., rinsing the crystalized calcium gluconate with water, ethanol, a mixture of water-ethanol.

In the aim of determining the procedure efficiency, for each experiment a yield of calciumgluconate was determined and compared with the theoretical yield calculated on the basis of stoichiometry reaction, whereas the percentage of calcium gluconate and bromide in the obtained crystal salt was determined by applying the method of atomic absorption spectroscopy, i.e., potentiometry.

\section{RESULTS AND DISCUSSION}

\subsection{Determining the optimal content of $\mathrm{KBr}$ in a working electrolyte}

The bromide content $(\mathrm{KBr})$ in a working electrolyte varies from $0,04 \mathrm{~mol} / \mathrm{dm}^{3}$ to $0,2 \mathrm{~mol} / \mathrm{dm}^{3}$ with other unchanged (optimized) parameters (current density - $2,5 \mathrm{~A} / \mathrm{dm}^{2}$; temperature $45 \pm 3^{0} \mathrm{C}$; content D-glucose- $0,5 \mathrm{~mol} / \mathrm{dm}^{3}$; added amount of calcium-carbonate of $0,5 \mathrm{~mol} / \mathrm{dm}^{3} ; \mathrm{pH}$-value $-6,5$ to 
7,5 ; reaction duration $7 \mathrm{~h}$, number of stirrer rotations $\mathrm{n}=300 \mathrm{~min}^{-1}$ ). Table 1 . shows experiment results of

determining the necessary content of $\mathrm{KBr}$ in the working electrolyte.

Table 1. Determining the optimal content of $\mathrm{KBr}$ in a working electrolyte

Tabela 1. Određivanje optimalnog sadržaja $\mathrm{KBr}$ u radnom elektrolitu

\begin{tabular}{|l|c|c|c|c|c|c|}
\hline Content $\mathrm{KBr}\left(\mathrm{mole} / \mathrm{dm}^{3}\right)$ & 0,20 & 0,125 & 0,10 & 0,085 & 0,05 & 0,04 \\
\hline Content $\mathrm{Br}^{-}$in Ca-gluconate (\%) & 2,5 & 1,5 & $1,4-1,6$ & $0,8-1,0$ & $0,5-0,6$ & $0,5-0,6$ \\
\hline Yield (\%) & $80-81$ & 81 & $81-83$ & 80 & $78-81$ & 60 \\
\hline Purity Ca-gluconate (\%) & $96-97$ & $96-97$ & 98 & 99 & 99 & \\
\hline
\end{tabular}

The given results show that, in the $\mathrm{KBr}$ content in the working electrolyte of $0,05 \mathrm{~mol} / \mathrm{dm}^{3}$, yield and calcium-gluconate purity are satisfactory high with the smallest amount of bromide in calciumgluconate.

\subsection{Determining the optimal anode current density}

The impact of applied anode current density on the process of forming calcium-gluconate is complex because at the same time it determines the duration of the electrochemical part of the process, and it also influences the termical cell balance, because in the function of the applied strength of the process current, there can occur a need to heat or cool the electrolyte. In the conducted series of experiments the density of the anode current varied from 1,2 to $20 \mathrm{~A} / \mathrm{dm}^{2}$ with other non-altered (optimal) parameters, i.e. content of D-glucose and potassium-bromide in the starting solution: respectively, 0,5 and $0,05 \mathrm{~mol} / \mathrm{dm}^{3}$ ), the added amount of calcium-carbonate $-0,5 \mathrm{~mol} / \mathrm{dm}^{3}$ ); temperature $45 \pm 3^{0} \mathrm{C}$; pH-value $-6,5$ to 7,5 , number of stirrer rotations $n=300 \mathrm{~min}^{-1}$. The duration of the experiment was inversely proportional determined with the current density. Table 2 . shows experiment results of determining the optimal anode current density.

Table 2. Determining the optimal density of anode current and duration of process

Tabela 2. Određivanje optimalne gustine anodne struje i trajanja procesa

\begin{tabular}{|l|c|c|c|c|c|c|c|}
\hline Anode current density (A/dm $\left.{ }^{2}\right)$ & 1,2 & 2,5 & 3,3 & 4,8 & 10 & 17,8 & 20 \\
\hline Electrolysis duration (h) & 13,5 & 7 & 3,5 & 3,5 & 1,7 & 0,8 & 0,8 \\
\hline Yield (\%) & 81 & $78-82$ & $73-75$ & 75 & 58 & 57 & 55 \\
\hline Purity Ca-gluconate (\%) & 99 & 99 & 96 & & & & \\
\hline
\end{tabular}

Considering the results of experiments conducted with anode current variations, one can conclude that the current density of $2,5 \mathrm{~A} / \mathrm{dm}^{2}$ with the process duration of $7 \mathrm{~h}$, regarding the calciumgluconate yield and purity with other applied process parameters, is optimal. An additional benefit is that with anode current density of $2,5 \mathrm{~A} / \mathrm{dm}^{2}$, in the applied electrolytical cell enough energy was released so that the working electrolyte after the initial heating to work temperature, did not need to be heated or cooled again. This conclusion, however, cannot be general because it depends on each specific solution of the electrolytic cell, the electrolyte content and type of electrode, manner and stirring intensity. For experiments where the current density is bigger than $4,5 \mathrm{~A} / \mathrm{dm}^{2}$, due to unsatisfactory yield, the purity of calciumgluconate was not determined at all.

\subsection{Determining the optimal amount of calcium- carbonate for adding to the electrolyte}

In additional series of experiments the previous researches regarding the amount of calciumcarbonate that should be added during the experiment to the working electrolyte were checked. Thereby, the amount of $\mathrm{CaCO}_{3}$ varied from 0,36 to $1,8 \mathrm{~mol} / \mathrm{dm}^{3}$, whereas the other parameters were constant: the content of $\mathrm{D}$ glucose: $0,5 \mathrm{~mol} / \mathrm{dm}^{3}$, content of $\mathrm{KBr}: 0,05 \mathrm{~mol} / \mathrm{dm}^{3}$, current density: $2,5 \mathrm{~A} / \mathrm{dm}^{2}$, experiment duration $-7 \mathrm{~h}$, $\mathrm{pH}$-values from 6,5 to 7,5 , number of stirring rotations: $\mathrm{n}=300 \mathrm{~min}^{-1}$. Calcium-carbonate in the form of powder is the working electrolyte dosed equally, divided into four identical parts, proportional to the experiment duration (before starting the experiment, and then after $1 / 4,1 / 2$ and $3 / 4$ experiment duration).

Table 3. Determining the optimal amount of $\mathrm{CaCO}_{3}$ that needs to be added to the working electrolyte during electrolysis

Tabela 3. Određivanje optimalne količine $\mathrm{CaCO}_{3}$ koji treba dodati radnom elektrolitu u toku elektrolize

\begin{tabular}{|l|c|c|c|c|}
\hline $\left.\begin{array}{l}\text { Addition } \mathrm{CaCO}_{3}, \\
(\text { mole/dm }\end{array}\right)$ & 0,36 & 0,5 & 0,7 & 1,8 \\
\hline Yield (\%) & 75,5 & 80,4 & 55,3 & 18,9 \\
\hline Purity Ca-gluconate (\%) & 98 & 97,5 & 96,5 & 90 \\
\hline
\end{tabular}

In the conducted experiments of adding calcium-carbonate into the working electrolyte the achieved result from the previous laboratory 
experiments of obtaining calcium-gluconate was confirmed. This proved that the optimal amount of $\mathrm{CaCO}_{3}$ which needed to be added during the electrolysis process was $0,5 \mathrm{~mol} / \mathrm{dm}^{3}$.

\subsection{Examining the purification processes of calcium-gluconate from remaining $\mathrm{KBr}$}

Since earlier experiments proved that bromides are always present in the electrochemically obtained calcium-gluconate in the form that in most cases significantly limits its application, removing bromide from the obtained calcium-gluconate was examined by applying numerous physical and chemical methods.

The simplest one, but the least suitable method is rinsing the crystal calcium-gluconate with distilled water. Dissolution $\mathrm{KBr}$ and calcium gluconate data in water, point out that the ratio of dissolution of both substances is unfavourable $(\mathrm{KBr}-66 \mathrm{~g} / 100 \mathrm{ml}$ $\mathrm{H}_{2} \mathrm{O}$, and Ca-gluconate- 3,5g/100ml $\mathrm{H}_{2} \mathrm{O}$ ) [21], which was proved in practical experiments because, after longer rinsing with water which is necessary for efficient decrease of bromide content, gluconate yield decreased about $40 \%$. Similar experiments with ethanol did not give adequate results because the dissolution of both substances is insignificant.

Removing bromide from the aqueous solution of calcium-gluconate can be achieved by precipitation methods. One of the possible precipitation agents is the base lead-carbonate $\left(\mathrm{PbCO}_{3} \cdot \mathrm{Pb}(\mathrm{OH})_{2}\right)$. Bromide precipitation was done with varying temperatures and process duration, and the most efficient bromide refinement with base lead-carbonate was achieved at temperature $80^{\circ} \mathrm{C}$ with the duration of two hours. The obtained lead-bromide, upon finishing precipitation, was separated by filtration. The procedure proved to be efficient, but as a consequence, had increased lead content in the crystal calcium-gluconate monohydrate from 0,1 to $0,3 \%$, and as such because of lead's famous toxicity was dismissed.

Removing bromide from the water solution of calcium gluconate was checked with precipitation of silver-nitrate. The reaction of silver ion with bromides at room temperature happened immediately, and the obtained precipitate of $\mathrm{AgBr}$ was removed by filtration. This procedure did not have a negative effect on the yield calcium gluconate, however, $\mathrm{Ca}\left(\mathrm{NO}_{3}\right)_{2}$ in the amount from 0,3 to $1 \%$, and $\mathrm{AgNO}_{3}$ in the amount of $1,0 \cdot 10^{-4} \%$ impurities occur in the crystal calcium-gluconate monohydrate. Impurity content disqualified the method of removing bromide by silver-nitrate precipitation.

Silver-oxide is one of the possible precipitation agents for bromide, so in one series of experiments this method of removing bromide was applied. The process was optimally carried at temperatures from 60 to $70^{\circ} \mathrm{C}$ with precipitation of two hours. It was determined that the amount of $\mathrm{Ag}_{2} \mathrm{O}$, was ten times less than the stoichiometry needed amount and enough for quantitative bromide precipitation from the calcium-gluconate solution. The cause of this was not explained. In the obtained calciumgluconate monohydrate after this refinement, bromides were completely eliminated, the content of silver was at highest $1,0 \cdot 10^{-4} \%$, or it was not there at all, whereas the yield of calcium-gluconate was less for about $2 \%$, which made the method technologically acceptable.

The last of the the examined methods of calcium gluconate refining was rinsing the calciumgluconate with a mixture of ethanol-water in volume ratio 1:1. Mass ratio of wet crystals of calciumgluconate and the mixture of ethanol-water varies within limits $1: 1$ to $1: 6$, and it was proved that the most suitable ratio is $1: 3,5$. After adding crystals into the solution of the mixture ethanol-water, the suspension is stirred intensively for 3 minutes and is filtrated immediately. Wet crystals are dried under vacuum $(\Delta p=20 \mathrm{mmHg})$ at $80^{\circ} \mathrm{C}$, and the dried crystals of calcium-gluconate monohydrate do not contain bromides, and among all of the examined refining methods, this one is the most suitable (it is the shortest, the cheapest, and does not contribute to introducing impurities into the product, and the amount of yield is less than 4\%).

\subsection{Phase (waste) process products}

In the process of obtaining calcium-gluconate monohydrate, phase (waste) products appear, out of which some can be recycled and used again in the process. After completing the electrochemical process of glucose oxidation from the working electrolyte, the remaining firm phase (waste residue) is removed by filtration. The chemical content of waste residue after drying is as follows: $\mathrm{CaCO}_{3}-96-97 \%$, bromides- 0,3-0,4\%, glucose $-0,5-$ $0,75 \%$, moisture - around $2 \%$, graphite- in traces. Obtained residue is treated as waste, but its reuse in preparing the working electrolyte should be considered and experimentally checked.

Upon separating waste residue, an equal volume of ethanol is added to the filtrate that contains calcium-gluconate and such a solution is left for 48 hours for the process of calciumgluconate crystallization. The obtained crystals of calcium-gluconate are separated by filtration, and such filtrate is of the following composition: calcium-gluconate-to $1 \mathrm{~g} / \mathrm{dm}^{3}$, bromides $-5-6$ $\mathrm{g} / \mathrm{dm}^{3}$, glucose $-5-10 \mathrm{~g} / \mathrm{dm}^{3}$, ethanol and water, $50 \%$ mass each. This solution together with the filtrate which is obtained in the process of rinsing the calcium-gluconate crystals with the aim of purifying from bromides (Fig. 3. marked as total 
filtrate), was submitted to vacuum distillation ( $\mathrm{t}=$ $38 \pm 5{ }^{\circ} \mathrm{C}$ and $\Delta p=80-100 \mathrm{mmHg}$ ), in order to recycle ethanol. The obtained distillate contains $70 \%$ ethanol and $30 \%$ water on average, was successfully used in the following experiments for preparing rinsing of calcium-gluconate crystals solution. The solution that remains after the vacuum evaporation, represents a waste solution and was not used in further experiments. Having in mind that this solution contains the highest amount of $\mathrm{KBr}$ brought into the process, there is justification for its reuse in the process, which should be checked and proved experimentally.

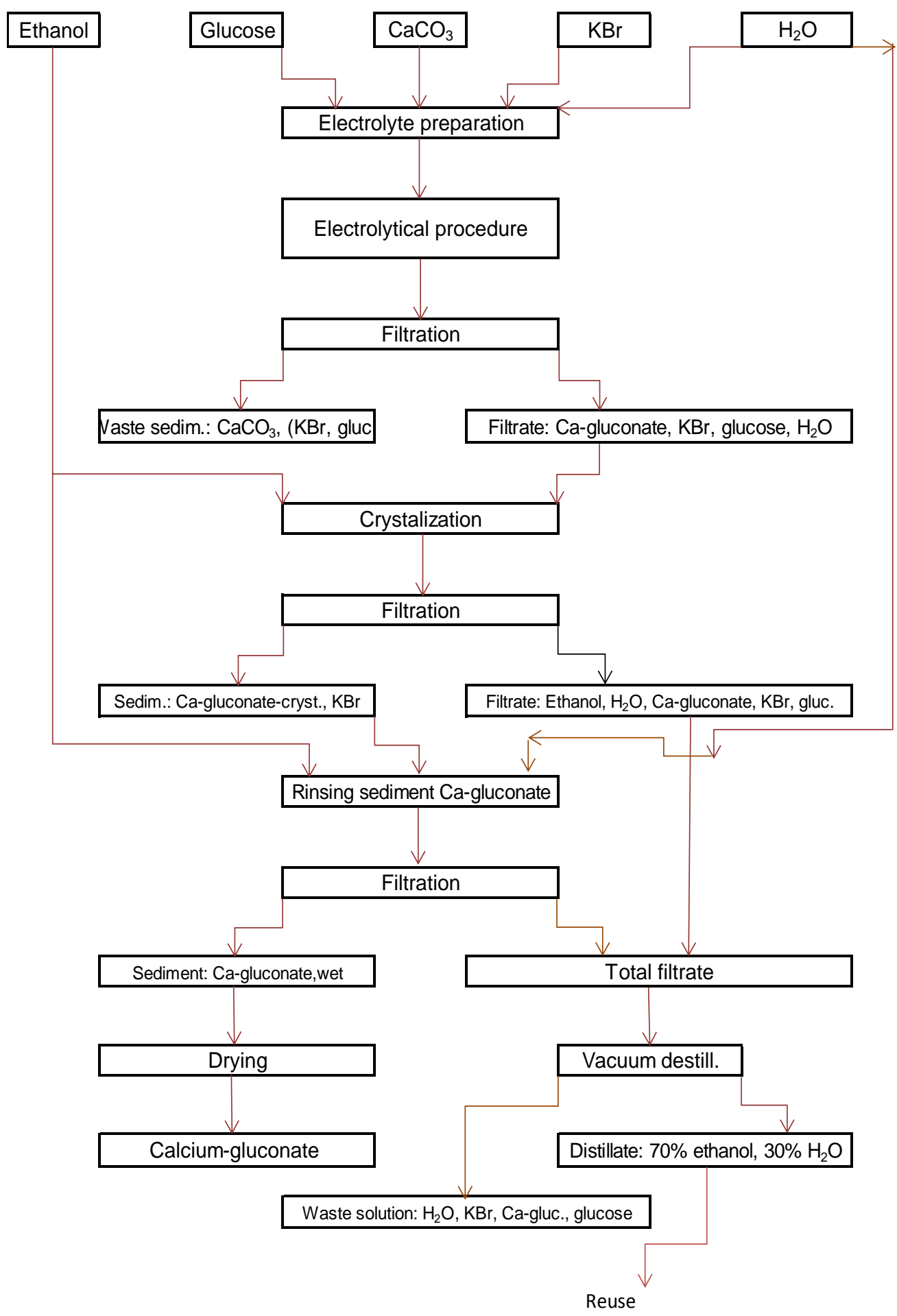

Figure 3. Block scheme of the proposed pilot-plant electrochemical process of obtaining calcium-gluconate Slika 3. Blok šema predloženog poluindustrijskog elektrohemijskog procesa dobijanja kalcijum-glukonata 


\subsection{Suggestion of a technological scheme for obtaining calcium-gluconate}

Based on all research results of obtaining calcium-gluconate monohydrate in an electrochemical way in enlarged laboratory apparatus, a block-scheme of a plant pilot-plant is suggested. At a pilot-plant level, with applying efficient electrolytical cells, it would be necessary to check all process parameters again determined in previous research, and especially, explain the recycling possibility of all phase (waste) precipitates and solutions formed in the process. Recent research, as being showed, confirmed the possibility of using the mixture ethanol-water that is obtained by vacuum vaporization of total filtrate (the liquid phases obtained in the calciumgluconate separation process after crystallization and the solution that is obtained in the process of rinsing calcium-gluconate crystal with the mixture of ethanol-water with the aim of removing bromide).

Fig. 3. shows the suggested block scheme of obtaining calcium-gluconate by electrochemical method.

\section{CONCLUSION}

Research of electrochemical procedure of obtaining calcium-gluconate monohydrate on enlarged laboratory apparatus, and the process of additional bromide product purification was conducted.

The electrochemical procedure is carried out in a cell with an electro-graphite anode and a copper cathode at temperature $45 \pm 3^{0} \mathrm{C}$, constantly mixing with magnetic stirrer $\mathrm{n}=300 \mathrm{~min}^{-1}$, anode current density of $2,5 \mathrm{~A} / \mathrm{dm}^{2}$ and process duration of $7 \mathrm{~h}$.

The working electrolyte consists of: D-glucose $\left(0,5 \mathrm{~mol} / \mathrm{dm}^{3}\right), \mathrm{KBr}\left(0,05 \mathrm{~mol} / \mathrm{dm}^{3}\right)$, while the powder of $\mathrm{CaCO}_{3}$ in the amount of $0,5 \mathrm{~mol} / \mathrm{dm}^{3}$ is added to the working electrolyte during the process in four equal parts.

After separating the firm phase from the working electrolyte at the end of electrolysis the filtrate obtained upon adding ethanol, remains $48 \mathrm{~h}$ for the crystallization of calcium-gluconate.

Calcium-gluconate crystals are mixed in 1:3,5 mass ratio with a mixture of ethanol-water (1:1) for the purpose of removing bromide, are briefly rinsed, and then separated by filtration. Wet calcium-gluconate crystals are dried under vacuum $(\Delta \mathrm{p}=20 \mathrm{mmHg})$ at $80^{\circ} \mathrm{C}$.

The described calcium-gluconate monohydrate does not contain bromide.
Ethanol from the solution after rinsing bromide from the crystal calcium-gluconate, can be purified by vacuum evaporation $\left(\mathrm{t}=38 \pm 5^{\circ} \mathrm{C}\right.$ and $\Delta \mathrm{p}=80$ $100 \mathrm{mmHg}$ ), and reused in the process.

Based on the research results a design of a pilot-plan process of obtaining calcium-gluconate monohydrate was suggested.

\section{REFERENCES}

[1] A.Padovani (2016) Glucose Oxidation into Gluconic Acid: From Batch to Trickle Bed Reactor, Dissertation for the academic degree of Doctor of Science; Faculty of Chemistry and Biochemistry of Ruhr-Universität Bochum.

[2] H.S.Isbell, H.L.Frush, F.J.Bates (1932) Glucose Oxidation into Gluconic Acid, Industrial and Engineering Chemistry , 24, 375-378.

[3] H.G.J.Dewilt (1972) Part I. Oxidation of Glucose to Gluconic Acid. Survey of Techniques, Industrial \& Engineering Chemistry Product Research and Development, 11, 370-373.

[4] R.H.Blom, V.F.Pfeifer, A.J.Moyer, D.H.Traufler, H. F. Conway, C. K. Crocker, R. E. Farison, D. V. Hannibal (1952) Sodium gluconate production, fermentation with Aspergillus niger., Industrial and Engineering Chemistry, 44, 435-440.

[5] S.Ramachandran, P.Fontanille, A.Pandey, C. Larroche (2006) Gluconic acid: properties, applications and microbial production, Food Technology and Biotechnology, 44, 185-195.

[6] M.Haruta, Y.Souma (1997) Copper, Silver and Gold in Catalysis, Catalysis Today, 36, 153-166.

[7] L.Prati, A.Villa, A.R.Lupini, G.M.Veith (2012) Gold on carbon: One billion catalysts under a single label, Physical Chemistry Chemical Physics, 14, 29692978.

[8] A.Villa, M.Schiavoni, L.Prati (2012) Material science for the support design: a powerful challenge for catalysis, Catalysis Science \& Technology, 2, 673682.

[9] X.Y.Liu, A.Wang, T.Zhang, C.Y.Mou (2013) Catalysis by gold: New insights into the support effect, Nano Today, 8, 403-416.

[10] Gluconic acid technology, (www.vogelbusch.com 31.07.2017).

[11] S.Morgunov, G.Igor (2007) Gluconic acid production, Recent Patents on Biotechnology, 1(2), 167-180.

[12] T.Trišović (2003) Kinetika elektrohemijske reakcije redukcije glukoze, doktorska disertacija, Tehnološko- metalurški fakultet, Beograd .

[13] K.Jayaraman, P.Subbiah, C.Seshadri, P. Thirunavukkarasu (2011) Bipolar flow cell for the production calcium gluconate, Bulletin of electrochemistry, 7 (6), 269-270.

[14] B.N.Grgur, D.L.Žugić, M.M.Gvozdenović, T.LJ. Trišović (2006) A kinetic study of D-glucose oxidation by bromine in aqueous solutions, Elsevier, Carbohydrate Research 341, 1779-1787. 
[15] D.Pletcher (1985) Recent developments in organic electrosynthesis, Rev. Port Quim., 27, 449-458.

[16] United State Patent Office (1933) Process for the electrolytic oxidation of aldoses. US Patent 1.937.273.

[17] European Patent Server (2002) Method of producing calcium gluconate, compositions, processes and uses of same, Patent EP 1516624 B1.

[18] European pharmacopoeia $9^{\text {th }}$ edition (https://www. edqm.eu/en/european-pharmacopoeia-9th-edition 17.09.2017).
[19] Calcium Gluconate Market 2016: Production, Sales, Supply, Demand, Analysis \& Forecast to 2021(https://www.linkedin.com/pulse/calciumgluconate-market-2016-production-sales-supplyarun-patil 06.08.2017.).

[20] Sandoz (1960) Patent DRP 461370, KI 120 vom 13.

[21] Calcium gluconate, (https://pubchem.ncbi.nlm.nih. gov/compound/calcium_gluconate\#section=Top 05.08.2017.).

\section{IZVOD}

\section{ELEKTROHEMIJSKA METODA ZA DOBIJANJE KALCIJUM - GLUKONATA}

Glukonska kiselina $i$ njene soli imaju široku primenu u mnogim granama industrije, medicini $i$ farmaciji. Kalcijum-glukonat se može dobiti delovanjem glukonske kiseline na odgovarajuća jedinjenja kalcijuma. U radu je primenjena metoda dobijanja kalcijum-glukonata elektrolizom vodenog rastvora glukoze u prisustvu $\mathrm{KBr} i \mathrm{CaCO}_{3}$, pri čemu nagrađena glukonska kiselina u rekaciji sa kalcijum-karbonatom gradi kalcijum-glukonat. Dokazano je da se primenom elektrohemijskog procesa i naknadnim postupkom prečićavanja, može dobiti kalcijum-glukonat monohidrat, bez primesa bromida. Takođe je dokazano da se etanol, koji se koristi u procesu može reciklirati i ponovo koristiti, što postupak čini ekonomičnijim i ekološki naprednijim. Na bazi rezultata istraživanja predložena je blok shema poluindustrijskog procesa dobijanja kalcijumglukonata monohidrata.

Ključne reči: kalcijum-glukonat; elektrohemijski postupak; uklanjanje bromide.

Naučni rad

Rad primljen: 23. 11. 2017.

Rad prihvaćen: 15. 02. 2018.

Rad je dostupan na sajtu: www.idk.org.rs/casopis

(C) 2018 Authors. Published by Engineering Society for Corrosion. This article is an open access article distributed under the terms and conditions of the Creative Commons Attribution 4.0 International license (https://creativecommons.org/licenses/by/4.0/) 